
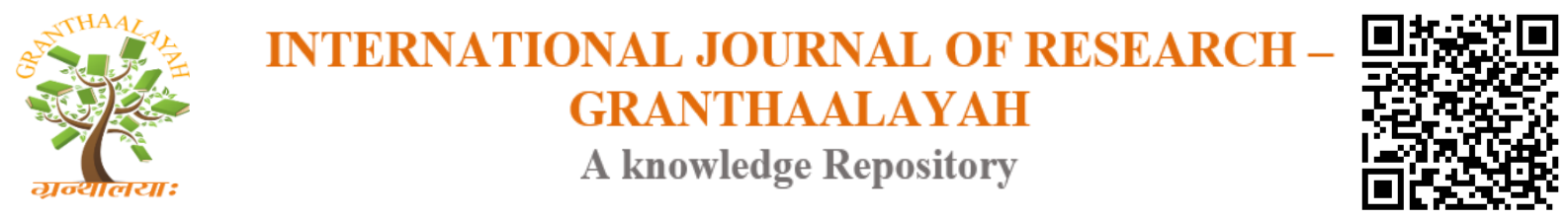

Science

\title{
APPLICATION OF ORGANIC MATTER ON ENTISOL-SOIL AFFECTED SOIL MOISTURE CAPACITY AND GROWTH OF MAIZE (Zea mays L.)
}

\author{
Domingos Pereira Gama ${ }^{1}$, Budi Prasetya ${ }^{2}$, Soemarno ${ }^{2}$ \\ ${ }^{1}$ Master of Soil-Water Management, Faculty of Agriculture, University of Brawijaya, Malang \\ ${ }^{2}$ Soil Sciences Department, Faculty of Agriculture, University of Brawijaya, Malang
}

\begin{abstract}
The research aimed to know growth of maize and soil moisture retention of the Luro-Entisol by application of organic matter. Field research was carried out in the Odofuro / Luro Timor Leste, analysis of soil samples was done in the Soil Physics Laboratory, Soil Science Department, Faculty of Agriculture, University of Brawijaya, and Malang. Field experiment used the split plot design, consisting of two factors and four replications, resulting in 24 units of experiments. The first factor is organic matter $(\mathrm{P})$ consisting of cow manure $(\mathrm{P} 1)$ and sheep manure $(\mathrm{P} 2)$, and the second factor is dosage of manure, including without fertilizer (D0), manure 5 tons ha-1 (D1) and manure of 10 tons ha-1. Results showed that dosage of manure has significantly effects on plant height, stem diameter, fresh weight and dry weight of stalk, but not significant effected the soil particle density, soil bulk density, total soil porosity and soil moisture.
\end{abstract}

Keywords: Maize; Organic Matter; Soil Moisture.

Cite This Article: Domingos Pereira Gama, Budi Prasetya, and Soemarno. (2018). "APPLICATION OF ORGANIC MATTER ON ENTISOL-SOIL AFFECTED SOIL MOISTURE CAPACITY AND GROWTH OF MAIZE (Zea mays L.).” International Journal of Research - Granthaalayah, 6(1), 187-202. 10.29121/granthaalayah.v6.i1.2018.1608.

\section{Introduction}

Maize is an important carbohydrate plant in the Timor Leste, thus increasing of domestic maize production to meet food needs in Timor Leste. The low degree of soil moisture becomes one of the limiting factors to increase maize production in drylands. The research results show that the improvement of physical, chemical and biological properties of soil can be done by application of organic matter into the soil, such as cow manure and sheep manure. This manure application can improve soil characteristics and improve the ability of soil to retain water, and improve growth and yield of maize. (Tisdall and Oades, 1982; Oades, 1984; Dao, 1993; Hudson, 1994; Franzluebbers, 2002; Mikha dan Rice, 2004; Bouajila dan Sanaa, 2011; Karami et al., 2012; Esmaeilzadeh dan Ahangar, 2014; Zhang, et al., 2014). 
The production of maize in Timor Leste averages 0.6 ton ha-1 (Da Costa et al., 2015), whereas the productivity of maize in the Australian Lockyer valley can reach 7-10 tons of ha-1 cobs. Rahmi and Jumiati (2007) reported that the productivity of maize in Samarinda City can reach 2.9 to 3.6 tons ha- 1 . This shows that the productivity of maize in Timor Leste, especially Lautem / Lospalos District has the potential to be improved. The low domestic maize production is due to the lack of water supply that can be utilized by plant during its growth. One of efforts in improving quality of drylands to cultivate maize crops is by soil tillage and adding organic matter into the soil (Mucheru-Muna et al., 2007; Basamba et al., 2007; Agbogidi dan Okonmah, 2012; Okoroafor et al., 2013).

The addition of organic matter into the soil can be expected to improve the quality of soil physics, increase the availability of soil nutrients, increase soil's ability to retain water that infiltrate into the soil to become available to plants, and improve plant growth. The addition of organic matter into the soil in the form of manure, green manure or crop residues can increase content of N and C in the soil (Shortall and Liebhardt, 1975; Food Crops Research Institute, 2015). The application of organic matter into the soil shoud be done with the appropriate dose (amount) to increase the productivity of plant (Negassa et al., 2001). Thus organic matter is referred as the dynamic agent, activator and soil regenerator in increasing productivity of soil and plants (Simarmata dan Hindersah, 1999; Boateng, Zickermann dan Kornahr, 2006; Kihanda, Warren, dan Micheni, 2006; Mahmood et al., 2017).

The applicable technology is by applying organic matter into the soil, with the aim of increasing soil's ability to retain water into the soil, thus becoming available for plant growth (Rahman, 2002).

Entisol is a soil of undeveloped profile, these soils are classified as young soil, which is still in the early stages of the genesis process, so it has not yet formed a pedogenic horizon. This soil has a weak aggregate stability due to the dominance of the sand fraction. Soil texture, nutrient content and organic matter content is determined by the soil parent material (Munir, 1996).

Entisol has a great potential to be developed into a productive agricultural land. Entisol has a pretty good chance for people's lives, because Entisol have developed along the river (Munir, 1996). Entisol has a very diverse soil reaction ranging from $\mathrm{pH} 2.5-8.5$, and the organic content is usually low.

Soil management of this soil type should involve adding organic materials to improve soil structure, and increasing $\mathrm{N}$-soil and reducing nutrient leaching losses. According to Munir (1996), to improve the soil structure to be granular need to be applied organic matter. Dryland is one of the land that has great potential for agriculture, food crops, horticulture (vegetables and fruits), perennial crops and livestock. The dominant problem in dryland management is the low availability of soil moisture, so the soil is not able to support growth of productive crops (Wigena et al., 2015).

Drylands in arid and semiarid climates are characterized by low rainfall of $1.000-1.500 \mathrm{~mm}$ year1 for 3-4 months, irregular rain distribution. Fluctuations in rainfall are very high, at one time reaching $100 \mathrm{~mm}$ day-1 or no rain at all for 2-3 weeks (Nasiu, 2012). 
An effort to improve the quality of dryland for cultivation of maize is indispensable. One effort that can be done is by adding organic matter into the soil. The high content of soil organic matter can maintain the physical quality of texture and soil structure to assist development and penetration of plant roots and smooth movement of soil moisture, through the formation of soil pores and stable soil aggregate. Soil organic matter physically and biologically plays the important roles, so as to determine the fertility status of a soil (Hanafiah, 2014). The quality of organic fertilizer is determined by the composition of the raw material and its decomposition rate (Zulkarnain et al., 2012).

Manure can affect the soil physical properties of soil porosity and increased moisture content, reduce soil bulk density, and improve infiltration capacity and soil-water retention (Agbede et al., 2008). The addition of organic matter into the soil is expected to improve quality of soil physics, increase the availability of nutrients in soil, increase the ability of soil to hold available water and able to improve plant growth (Tangkoonboribun et al., 2007).

According to Kohnke (1979, in Muyassir et al., 2010), the role of organic matter in soil physics properties are to improve soil aggregation and soil structure. According to Judge (1986, in Intara et al., 2011) the application of organic matter can increase nutrients reserve in soil, and improve soil structure.

Unstable soil structure and low organic matter content in soil can affect bulk-density , and soil porosity (Bodansari, 2012). The ability of soil to retain water is influenced by soil texture and soil organic matter content (Intara, et al., 2011). Syukur and Indah (2005) found that the lower rates of manure applied into the soil cause the holding water pores to be lower, thus affecting the soil moisture content.

Water retention is ability of soil to retain water or hold water in soil pores, and / or release water from soil pores. This depends on soil physical properties, namely soil texture, soil structure, soil macropore and micropore, soil drainage, air temperature and rainfall. Thus to quantify water requirements and optimize the use of water, it is necessary information about the retention of water in soil. Soil moisture retention are highly dependent on soil texture and soil structure, mesopores and micropores, soil drainage, air temperature and rainfall. Information on water requirements and optimization of water use is essential in relation to agricultural planning (Kurnia et al., 2006).

Soil moisture retention is ability of the soil to retain water in soil pores, while the $\mathrm{pF}$ value reflects the water suction by the surface of soil particles. The smaller amount of available water in soil pore, the more difficult plant roots to absorb soil water. The ability of soil to hold water is in the range of $\mathrm{pF} 2.54-4.2$.

\section{Material and Methods}

\subsection{Location and Time of Research}

The research was conducted at Entisol- Luro located in Kotamutu, Luro Sub-District, Lautem (Lospalos) District, with altitude of $19 \mathrm{~m}$ asl and topography 5\%. This field research took place 
during June-August, and November-October 2017. Field experiment using Split Plot Design, consisting of 2 factors and 4 replicates. The first factor (main plot) is the type of manure (P1 = cow manure) and ( $\mathrm{P} 2=$ sheep manure), the second factor (sub plot) is manure dose $(\mathrm{D} 0=$ control, D1 $=5$ tons ha- 1 , and D2 $=10$ tons ha- 1 .

\subsection{Field Experiment}

These researches was conducted in the field and in the laboratory to study growth of maize, namely plant height, stem diameter, leaf area and dry weight of stover; while the observation of soil physical properties included soil bulk density, particle density, soil porosity and water content of $\mathrm{pF} 2.5$ and 4.2. Analysis of soil chemical properties includes N-total and C-organic. Measurement of soil physical and chemical properties is done in the Soil Physics and Chemistry Laboratory, Faculty of Agriculture, University of Brawijaya; while plant growth analysis was conducted in the field and in the laboratory of the University of Timor-Lorosa'e, Timor Leste.

\subsection{Data Analysis}

Data of the research were analyzed statistically using Analysis of variance (Anova) to know effects of treatment or significance of difference between treatments. The analysis was continued with a LSD (5\%) test if treatments suggest the significant effect.

\section{Results and Discussion}

Table 1: Soil sample analysis before application of manure

\begin{tabular}{|l|l|l|l|l|l|l|l|}
\hline $\begin{array}{l}\text { Soil } \\
\text { Depth }\end{array}$ & $\begin{array}{l}\text { N-Total } \\
(\boldsymbol{\%})\end{array}$ & $\begin{array}{l}\text { C-organic } \\
(\boldsymbol{\%})\end{array}$ & $\begin{array}{l}\text { BIT } \\
\mathbf{g ~ c m}^{-3}\end{array}$ & $\begin{array}{l}\text { BJT } \\
\mathbf{g ~ c m}^{-3}\end{array}$ & $\begin{array}{l}\text { Porosity } \\
\text { \% }\end{array}$ & KL & KLP \\
\hline Topsoil & $0.10^{\mathrm{SR}}$ & $1.62^{\mathrm{SR}}$ & $1.33^{\mathrm{T}}$ & $2.35^{\mathrm{TM}}$ & $43.27^{\mathrm{S}}$ & $0.34^{\mathrm{S}}$ & 0.14 \\
\hline Subsoil & $0.07^{\mathrm{SR}}$ & $1.26^{\mathrm{SR}}$ & $1.37^{\mathrm{T}}$ & $2.36^{\mathrm{TM}}$ & $42.59^{\mathrm{S}}$ & $0.34^{\mathrm{S}}$ & 0.16 \\
\hline
\end{tabular}

Source: Soil Physics Laboratpry, Soil Science Dept., Fac. of Agriculture (2007), Ministry of Agriculture (1983) in Suhariyono et al. (2005)

Note: BIT= Soil Bulk Density, BJT = Soil Particle Density, KL= Field Moisture Capacity, KLP= Permanent Wilting Point, $\mathrm{SR}=$ Very Low, $\mathrm{S}=$ Moderate, $\mathrm{R}=\mathrm{Low}, \mathrm{TM}=$ Mineral Soil, $\mathrm{T}=$ High.

Table 1 shows that the soil in the experimental site suggests $\mathrm{N}$-total and C-roganic content, soil bulk-density, soil particle density, soil porosity and field moisture capacity, categorized into the very- low to moderate, so the quality of soil needs to be improved by applying organic matter into the soil. 


\subsection{Effect of Organic Matter of Maize Growth}

\subsubsection{Plant Height (cm)}

Table 2: Plant height of maize $(\mathrm{cm})$ at 2, 4, and 6 weeks after planting (MST) under application

\begin{tabular}{|l|c|c|c|}
\hline \multicolumn{4}{|c|}{ of manure } \\
\hline & \multicolumn{3}{|c|}{ Height of plant (cm) } \\
\hline Mainplot & & & \\
\hline P1 & 29.03 & 74.48 & 148.97 \\
\hline P2 & 30.98 & 81.7 & 150.86 \\
\hline LSD 5\% & $\mathrm{ns}$ & $\mathrm{ns}$ & $\mathrm{ns}$ \\
\hline Subplot & & & \\
\hline D0 & 30.28 & $66.69 \mathrm{~b}$ & $138.54 \mathrm{a}$ \\
\hline D1 & 27.37 & $79.25 \mathrm{a}$ & $145.58 \mathrm{~b}$ \\
\hline D2 & 32.36 & $88.33 \mathrm{a}$ & $165.62 \mathrm{~b}$ \\
\hline LSD 5\% & $\mathrm{ns}$ & & \\
\hline
\end{tabular}

Note: Number in a coulomb followed by same letters are not significsnt different under LSD $(5 \%)$ test. $\mathrm{P} 1=$ Cow manure, $\mathrm{P} 2=$ Sheep manure, $\mathrm{D} 0=$ Control, $\mathrm{D} 1=$ Dosage of manure 5 ton ha$1, \mathrm{D} 2=$ Dosage of manure 10 ton ha-1. ns= not significant different. MST $=$ weeks after planting.

Table 2 shows that the manure treatment did not significantly affect the height of maize plants at ages 2, 4 and 6 WAT. The average height of maize tended to be higher at P2 treatments. The average height of maize tends to be lower at P1 treatments. Treatment of manure dose had significant effect on the height of maize aged 4 and 6 WAT. Treatment of manure dose of 5 ton ha-1 and 10 ton ha-1 were not significantly different, but both were significantly different from control treatment. The highest plant was achieved in the D2 treatment and the lowest on treatment D0. This growth of plant-height is thought to be caused by the nutrients available in the soil. Rachman, et al (2015) found that the activity of soil organisms increases if the soil is given organic matter. Nariratih et al. (2013); Subaedah, Aladin and Nirwana (2016) found that increase of $\mathrm{N}$-available in the soil due to application of fertilizers and organic materials can improve growth of maize.

Table 3: Diameter of maize stem $(\mathrm{mm})$ at 2, 4, and 6 weeks after planting (MST) under application of manure

\begin{tabular}{|l|l|l|l|}
\hline Treatment & \multicolumn{3}{|c|}{ Diameter of Stem (mm) } \\
\hline & 2MST & 4 MST & 6 MST \\
\hline MAinplot & & & \\
\hline P1 & 3.30 & 14.00 & 22.70 \\
\hline P2 & 3.32 & 13.31 & 23.85 \\
\hline LSD 5\% & $\mathrm{ns}$ & $\mathrm{ns}$ & $\mathrm{ns}$ \\
\hline Subplot & & & \\
\hline D0 & 3.2 & $11.23 \mathrm{a}$ & $19.92 \mathrm{a}$ \\
\hline D1 & 3.11 & $13.49 \mathrm{~b}$ & $19.54 \mathrm{~b}$ \\
\hline D2 & 3.62 & $16.26 \mathrm{~b}$ & $25.56 \mathrm{~b}$ \\
\hline LSD 5\% & $\mathrm{ns}$ & & \\
\hline
\end{tabular}


Note: Number in a coulomb followed by same letters are not significsnt different under LSD $(5 \%)$ test. $\mathrm{P} 1=$ Cow manure, $\mathrm{P} 2=$ Sheep manure, $\mathrm{D} 0=$ Control, $\mathrm{D} 1=$ Dosage of manure 5 ton ha$1, \mathrm{D} 2=$ Dosage of manure 10 ton ha- $1 . \mathrm{ns}=$ not significant different. MST $=$ weeks after planting. The application of organic matter has no effect on the diameter of maize stalks at ages 2, 4 and 6 WAT. Manure dose did not have significant effect on diameter of maize plant of 2 WAT, while at age 4 and 6 WAT had significant effects. The manure dose of 5 ton ha- 1 and 10 ton ha- 1 were not significantly different, but both were significantly different from the control treatment. The highest stem diameter of maize plants $(25.56 \mathrm{~mm})$ was obtained in the D2 treatment. The lowest diameter of stem was obtained in the control treatment $(19.92 \mathrm{~mm})$. Wang et al. (2017) found that the application of organic fertilizer can improve soil fertility and improve growth of maize crops. The research results of Nuro et al. (2016) showed that addition of organic matter into the soil can improve soil fertility. While the research results of Singh et al. (2014) showed that decrease of root growth was related to soil quality, nutrients uptake and plant growth.

Table 4: Leaf area of maize (cm2) at 2, 4, and 6 weeks after planting (MST) under application of manure

\begin{tabular}{|l|c|c|}
\hline Treatment & Leaf area $\left(\mathbf{c m}^{2}\right)$ & BKB (g) \\
\hline Mainplot & & \\
\hline P1 & 509.90 & $68.43 \mathrm{a}$ \\
\hline P2 & 532.26 & $77.18 \mathrm{~b}$ \\
\hline$L S D 5 \%$ & $\mathrm{~ns}$ & \\
\hline Subplot & & \\
\hline D0 & $393.26 \mathrm{~b}$ & $57.50 \mathrm{a}$ \\
\hline D1 & $534.79 \mathrm{a}$ & $71.25 \mathrm{~b}$ \\
\hline D2 & $622.79 \mathrm{a}$ & $89.66 \mathrm{c}$ \\
\hline$L S D 5 \%$ & $\mathrm{~ns}$ & \\
\hline
\end{tabular}

Note: Number in a coulomb followed by same letters are not significant different under LSD $(5 \%)$ test. $\mathrm{P} 1=$ Cow manure, $\mathrm{P} 2=$ Sheep manure, $\mathrm{D} 0=$ Control, $\mathrm{D} 1=$ Dosage of manure 5 ton ha1, D2 = Dosage of manure 10 ton ha-1. ns= not significant different. BKB= shoot dry weight.

Table 4 showed that the manure treatment had no significant effect on the leaf-area of maize, but P2 treatment tended to produce larger leaf area $(532.26 \mathrm{~cm} 2)$ and the smallest leaf area on treatment P1 $(509.90 \mathrm{~cm} 2)$. The treatment of manure dose had significant effect on leaf area of maize. The dose of manure 5 tons ha- 1 and 10 tons ha- 1 were not significantly different, but both were significantly different with control treatment. The highest leaf area was achieved at dose of manure 10 tons ha-1 (D2) of 622,795 cm2, the smallest leaf-area in the control treatment (D0) is $393.26 \mathrm{~cm} 2$. Manure contains complete nutrients and has the ability to improve soil structure and soil aggregation, so as to store more available water for plant roots. This soil quality improvement causes the plant to absorb more water for better growth and leaf formation. Intara et al. (2011) found that the amount of water available in soil depends on the soil ability to hold infiltrated water from the soil surface. The results of Kresnatita et al. (2017) showed that the manure application of 10 ton ha- 1 could produce leaf-area of maize $3812.26 \mathrm{~cm} 2$ at age 44 days after planting (DAT).

Table 4 shows the treatment of manure significantly different to dry weight of stover. The highest dry weight of plants $(77.18 \mathrm{~g})$ was obtained at treatment P2, and the lowest dry weight of 
plant (68.43 g) was obtained at treatment P1. Manure dose treatment had significant effect on dry weight of maize plant. The largest dry weight $(89.66 \mathrm{~g})$ was achieved at a dose of manure of 10 tons ha-1; and the lowest (57.50 g) was obtained in the control treatment. Manure can increase soil water storage, so that water availability for plants can be fulfilled and soil microorganism better. Thus, plants can absorb nutrients and water sufficiently for growth and expansion of leaves. This increase in leaf area affects the process of photosynthesis of plants, so that the results of photosynthesis can be utilized for the growth of plant stems, and increased dry weight of plants. Putra et al. (2016) found that an increase in soil organic matter content can improve the soil ability to hold available water. Furthermore the application of organic matter can increase the soil organic matter content and improve the physical properties of soil (Zulkarnain et al., 2012). Rizqullah et al. (2017) found that with a manure application of 20 tons ha-1 can produce dry weight of plants of $74.83 \mathrm{~g}$ plant-1 (age 42 DAT). The rapid growth of leaves and stems requires sufficient water, the plants undergoing water stress, smaller individual leaves size and lower total leaf area (Muchow 1989, in Huang et al., 2006).

\subsection{Effects of Manure Application on Soil Characteristics}

\subsubsection{Soil Bulk Density (g cm-3)}

Results of analysis in Table 5 showed that treatment of manure application did not significantly affect the soil bulk density.

Table 5: Soil bulk density ( $\mathrm{g} \mathrm{cm}-3)$ under two kinds of manure and three dosage of manure application

\begin{tabular}{|l|c|c|c|c|}
\hline \multirow{2}{*}{ Treatment } & \multicolumn{3}{|c|}{ Soil Bulk Density $\left(\mathbf{g ~ c m}^{-3}\right)$} \\
\cline { 2 - 5 } & \multicolumn{2}{|c|}{ Before } & \multicolumn{2}{c|}{ AFter } \\
\cline { 2 - 5 } \multicolumn{2}{|l}{..... soil depth (cm).......... } \\
\cline { 2 - 5 } & $0-20$ & $20-40$ & $0-20$ & $20-40$ \\
\hline Mainplot & & & & \\
\hline P1 & 1.34 & 1.36 & 1.31 & 1.31 \\
\hline P2 & 1.32 & 1.37 & 1.3 & 1.33 \\
\hline LSD 5\% & $\mathrm{ns}$ & $\mathrm{ns}$ & $\mathrm{ns}$ & $\mathrm{ns}$ \\
\hline Subplot & & & & \\
\hline D0 & 1.33 & 1.36 & 1.32 & 1.32 \\
\hline D1 & 1.33 & 1.36 & 1.31 & 1.33 \\
\hline D2 & 1.34 & 1.38 & 1.28 & 1.31 \\
\hline LSD 5\% & $\mathrm{ns}$ & $\mathrm{ns}$ & $\mathrm{ns}$ & $\mathrm{ns}$ \\
\hline
\end{tabular}

Note: $\mathrm{P} 1=$ Cow manure, $\mathrm{P} 2=$ Sheep manure, $\mathrm{D} 0=$ Control, $\mathrm{D} 1=$ Dosage of manure 5 ton ha-1, D2 $=$ Dosage of manure 10 ton ha- 1. ns $=$ not significant different.

Table 5 shows the manure type and dose did not significantly affect the bulk density of the soil. This is because the applied organic material has not been able to improve the physical characteristics of the soil, because it has not been decomposed during the relatively short research period of 42 days. This is in line with research results Istiqomah et al. (2015) which suggests that the decomposition of organic matter in the soil takes a long time. 
The average bulk density of soil after manure application tends to be higher at P1 treatment (1.31 $\mathrm{g} \mathrm{cm}-3)$ and soil bulk density tends to be lower at D2 treatment $(1.28 \mathrm{~g} \mathrm{~cm}-3)$ at $0-20 \mathrm{~cm}$ of soil depth; whereas at $20-40 \mathrm{~cm}$ of soil depth the soil bulk density tends to be higher at P2 treatment (1.33 g cm-3) and D1 (1.33 g cm-3). This is due to the treatment of P2 with a soil depth of 0-20 $\mathrm{cm}$ containing more organic material resulting in lower bulk density of the soil. Organic matter as a soil adhesive can bind soil particles into a larger aggregate, so as to produce pores between soil aggregates, and affects the bulk density of soil. Rachman et al. (2015) found that soil aggregation greatly affects several soil physics properties, in particular the bulk density of soil and soil pores. Organic matter as an adhesive agent of soil particles, organic materials can enhance soil organisms, producing organic compounds that can bind soil particles to form the larger aggregates (Shalsabila et al., 2017). Results of Baskoro and Taringan (2017) showed that organic matter improved the soil physics properties, i.e. increasing porosity of the soil, soil aeration and stabilizing the soil aggregates.

\subsubsection{Soil Particle Density (g cm-3)}

Results of analysis presented in Table 6 show that the manure application has no significant effects on the particle density of soil. The soil particle densities under treatments of manure application are presented in Tablel 6.

Table 6: Soil Particle Density (g cm-3) under application of manure.

\begin{tabular}{|l|c|c|c|c|}
\hline \multirow{2}{*}{ Treatment } & \multicolumn{3}{|c|}{ Soil Particle Density $\left(\mathbf{g ~ c m}^{-3}\right)$} \\
\cline { 2 - 5 } & \multicolumn{3}{|c|}{ Before } & \multicolumn{3}{c|}{ After } \\
\cline { 2 - 5 } \multicolumn{2}{|c|}{ Soil depth (cm) } \\
\cline { 2 - 5 } & $0-20$ & $20-40$ & $0-20$ & $20-40$ \\
\hline Mainplot & 2.36 & 2.35 & 2.31 & 2.34 \\
\hline P1 & 2.34 & 2.41 & 2.30 & 2.35 \\
\hline P2 & $\mathrm{ns}$ & $\mathrm{ns}$ & $\mathrm{ns}$ & $\mathrm{ns}$ \\
\hline LSD 5\% & & & & \\
\hline Subplot & 2.39 & 2.38 & 2.32 & 2.34 \\
\hline D0 & 2.32 & 2.36 & 2.31 & 2.33 \\
\hline D1 & 2.35 & 2.39 & 2.3 & 2.37 \\
\hline D2 & $\mathrm{ns}$ & $\mathrm{ns}$ & $\mathrm{ns}$ & $\mathrm{ss}$ \\
\hline LSD 5\% &
\end{tabular}

Note: $\mathrm{P} 1=$ Cow manure, $\mathrm{P} 2=$ Sheep manure, $\mathrm{D} 0=$ Control, D1= Dosage of manure 5 ton ha-1, D2 $=$ Dosage of manure 10 ton ha- 1. ns $=$ not significant different.

Table 6 shows no significant effects of treatments on the soil particle density. This is because the applied manure has not been able to improve soil structure destroyed by soil tillage, because the research time is very short. Abdulrahman et al. (1986, in Baskoro et al., 2017) found that effects of organic matter application on the soil physical properties was significant after two years.

The manure application had no significant effect on soil particle density, but the particle density of manured soil decreased slightly compared with the unmanured soil (Table 6). The average particle density of topsoil $(0-20 \mathrm{~cm})$ tends to be lower at P2 treatment $(2.30 \mathrm{~g} \mathrm{~cm}-3)$. While at $20-40 \mathrm{~cm}$ of soil depth, the average particle density tends to be lower under manure application 
(2.39 $\mathrm{g} \mathrm{cm}-3)$. Organic matter can increase the activity of soil microorganisms, producing organic compounds that can bind soil particles into larger soil aggregates, thereby reducing soil density, increasing sol pore and increasing water infiltration, thus resulting in the decrease of soil bulk density. Dermiyati (2015) found that organic materials can improve soil physics properties, such as improving soil structure and reducing soil plasticity. While Syukur and Indah (2005) found that application of organic materials can reduce soil plasticity, and improve soil aeration. Organic matter increases soil aggregation, soil porosity and soil aeration (Rachman et al., 2015). The low content of soil organic matter affects the bulk density of the soil (Bondansari, 2012).

\subsubsection{Soil Porosity (\%)}

Results of data analysis in Table 7 showed that the type and dose of manure applied into the soil had no significant effect on soil porosity. The porosity of soil at manure treatments are presented in Table 7.

Table 7: Soil Porosity (\%) under application of manure

\begin{tabular}{|c|c|c|c|c|}
\hline & \multicolumn{4}{|c|}{ Soil Porosity (\%) } \\
\hline \multirow{3}{*}{ Treatment } & \multicolumn{2}{|c|}{ Before } & \multicolumn{2}{|c|}{ After } \\
\hline & \multicolumn{4}{|c|}{ Soil depth $(\mathrm{cm})$} \\
\hline & $0-20$ & $20-40$ & $0-20$ & $20-40$ \\
\hline \multicolumn{5}{|l|}{ Mainplot } \\
\hline P1 & 43.10 & 42.17 & 43.56 & 43.35 \\
\hline $\mathrm{P} 2$ & 43.43 & 43.02 & 45.78 & 44.63 \\
\hline$L S D 5 \%$ & $\mathrm{~ns}$ & $\mathrm{~ns}$ & $\mathrm{~ns}$ & $\mathrm{~ns}$ \\
\hline \multicolumn{5}{|l|}{ Subplot } \\
\hline D0 & 44.19 & 42.99 & 43.52 & 42.98 \\
\hline D1 & 42.50 & 42.51 & 44.34 & 44.27 \\
\hline D2 & 43.11 & 42.28 & 46.66 & 44.73 \\
\hline LSD 5\% & ns & ns & ns & ns \\
\hline
\end{tabular}

Note: P1 = Cow manure, P2= Sheep manure, D0=Control, D1= Dosage of manure 5 ton ha-1, D2 $=$ Dosage of manure 10 ton ha- 1 . ns $=$ not significant different.

Effects of manure on the soil porosity presented in Table 7 shows that manure treatment has no significant effect on increasing the soil porosity. However, there is a tendency that soil porosity increases after manure application. The average porosity of soil tends to be higher achieved at treatment D2 (46.66\%) and tends to be lower in treatment of without manure.

Sol organic matter are functioned as adhesive agents for the primary particles of soil into a larger soil aggregate, thereby reducing soil bulk density, and increasing the number of soil pores. Sukmawati (2015) found that soil physics characteristics can be improved by applying the organic farming technologies. Ariska et al. (2016) found that a high C-organic content can decrease the soil bulk density and increase the stable soil aggregates, so that the soil pore formation will change and soil porosity increases. Surya et al. (2017) found that manure applications can improve the life of soil microorganisms, increase soil fertility, improve soil structure and soil porosity. Satriya et al. (2016) reported that soil aggregate stability is affected by soil organic matter content. According to research results Sumarni et al. (2010), soil porosity 
is strongly influenced by soil organic matter content. Unstable soil structure and low soil organic matter can affect soil bulk density and particle density of soil, and soil porosity (Bodansari, 2012). Applications of organic fertilizers (from different sources) can increase soil porosity, soil moisture content and water holding capacity, while reducing soil compaction and improving soil bulk density (Papini et al., 2011, in Mahmood et al., 2017).

\subsubsection{Moisture Content Pf 2, 5 And 4, 2}

The result of the analysis showed that manure type and dose treatments had no significant effects on field moisture capacity and permanent wilting point. The mean field moisture capacity and permanent wilting point under manure treatments are presented in Table 8.

Table 8: Soil moisture content $(\mathrm{cm} 3 \mathrm{~cm}-3)$ at $\mathrm{pF} 2.5$ and $\mathrm{pF} 4.2$ under manure application

\begin{tabular}{|c|c|c|c|c|c|c|}
\hline & \multicolumn{4}{|c|}{ Soil moisture (cm3 cm-3) } & \multirow{2}{*}{\multicolumn{2}{|c|}{ Available moisture capacity $\left(\mathrm{cm}^{3} \mathrm{~cm}^{-3}\right)$}} \\
\hline & \multicolumn{4}{|c|}{ pF 4.2} & & \\
\hline \multirow[t]{2}{*}{ Treat-ment } & \multicolumn{6}{|c|}{..........soil depth (cm).............. } \\
\hline & $0-20$ & $20-40$ & $0-20$ & $20-40$ & $0-20$ & $20-40$ \\
\hline \multicolumn{7}{|l|}{ Mainplot } \\
\hline P1 & 0.37 & 0.35 & 0.20 & 0.21 & 0.17 & 0.14 \\
\hline $\mathrm{P} 2$ & 0.38 & 0.37 & 0.18 & 0.19 & 0.20 & 0.18 \\
\hline LSD 5\% & ns & ns & ns & ns & & \\
\hline \multicolumn{7}{|l|}{ Subplot } \\
\hline D0 & 0.36 & 0.36 & 0.20 & 0.20 & 0.16 & 0.16 \\
\hline D1 & 0.38 & 0.36 & 0.18 & 0.20 & 0.20 & 0.16 \\
\hline D2 & 0.39 & 0.35 & 0.18 & 0.20 & 0.21 & 0.15 \\
\hline$L S D 5 \%$ & ns & ns & ns & ns & & \\
\hline
\end{tabular}

Note: $\mathrm{P} 1=$ Cow manure, $\mathrm{P} 2=$ Sheep manure, D0=Control, D1= Dosage of manure 5 ton ha-1, D2 $=$ Dosage of manure 10 ton ha-1. ns= not significant different.

Table 8 shows that soil moisture content at field capacity and permanent wilting point, soil moisture measurement results with "presume plate apparatus" method at $\mathrm{pF} 2.5$ and $\mathrm{pF} 4.2$, are not influenced by manure application, but there is little increase in field moisture capacity compared to before application of manure. This is an indicator of the improvement of soil characteristics caused by manure application. Gatenby (1986, in Samudro, 2014) found that low soil organic matter content decreased soil microorganism activity and decreased soil porosity. Research of Wahyunie et al. (2012) showed that the soil organic matter content had an effect on the soil pore distribution. Hanafiah (2014) also found that soil macropore led to improve soil aeration and soil drainage. Size distributions of soilpores play an important role in the mechanism of soil moisture movement (Baskoro et al., 2017). The application of organic matter can decrease the soil bulk density and increase soil porosity (Sukawati, 2015). 


\section{Relation between Soil Characteristics and Shoot Dry Weight of Maize (BKB)}

\subsection{Soil Bulk Density vs. Shoot Dry Weight of Maize}

The result of regression analysis (Figure 1) shows that there is a tendency of a negative relationship between the dry weight of plant and the bulk density of soil, if the soil bulk density increase, the weight of plant decrease.

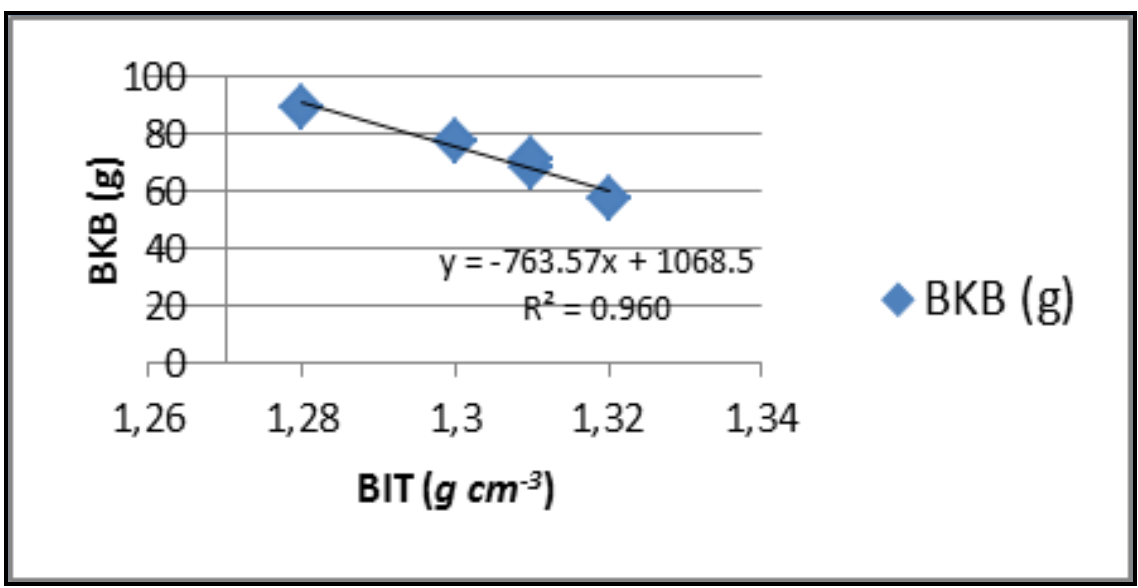

Figure 1: The relation between soil bulk density (BIT) and shoot dry weight of maize (BKB)

Results of the correlation and regression test between soil bulk density and dry weight of plants show the coefficient of determination (soil depth 0-20 cm) of R2 $=0.960$ (Figure 1). Results of this analysis indicate a negative relationship, i.e. the higher the value of soil-bulk density, the value of plant dry weight decreased. Mosaddeghi et al. (2000) found that the addition of manure or organic matter into the soil may reduce soil bulk-density.

\subsection{Soil Porosity vs. Shoot Dry-Weight of Maize (BKB)}

The results of correlation and regression analysis (Figure 2) showed a linear relationship between soil porosity and dry weight of the plant.

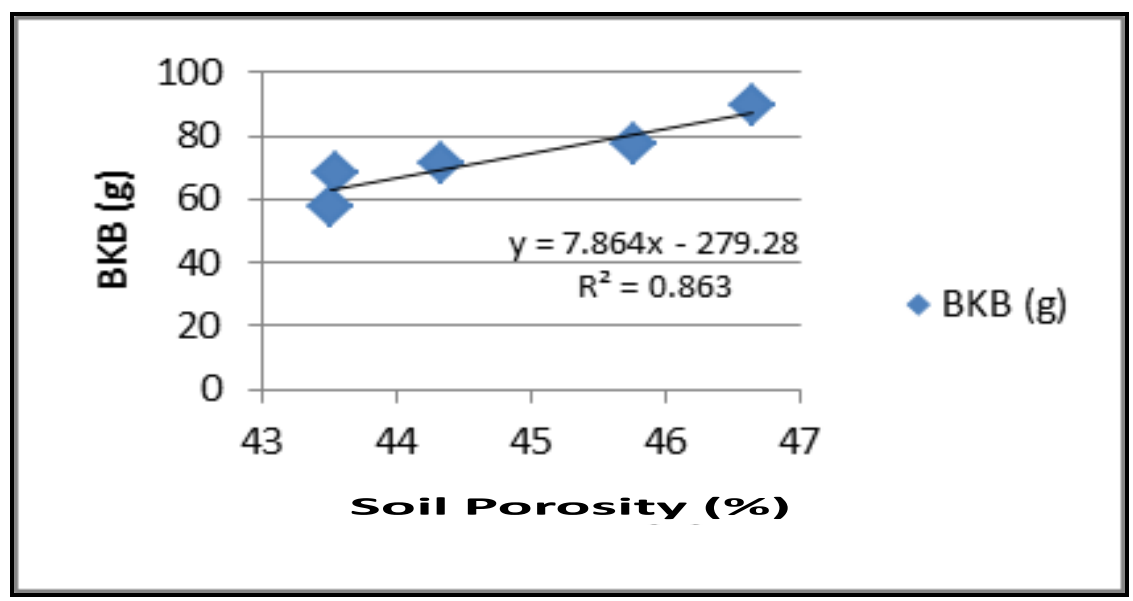

Figure 2: The relation between soil porosity and shoot dry weight of maize (BKB). 
The coefficient of determination on topsoil is $\mathrm{R} 2=0.863$, and on subsoil is $\mathrm{R} 2=0.795$. Results of this analysis indicate a linear relationship between soil porosity and dry weight of plants; the higher porosity of the soil value of dry weight of plants greater. Increasing the soil porosity can facilitate the penetration of plant roots to absorb water and nutrients in the soil, improving soil aeration for root repiration. According to Jones (1992, in Rahman, 2004), that the photosynthesis of plants that produce dry matter, is strongly influenced by leaf area.

\section{Relation between Soil Moisture Content at Field Capacity and Shoot Dry Weight of Maize (BKB)}

Regression analysis result (Figure 3) shows that there is a linear relationship between field moisture capacity ( $\mathrm{pF} 2.5$ ) of soil and the dry weight of maize stover.

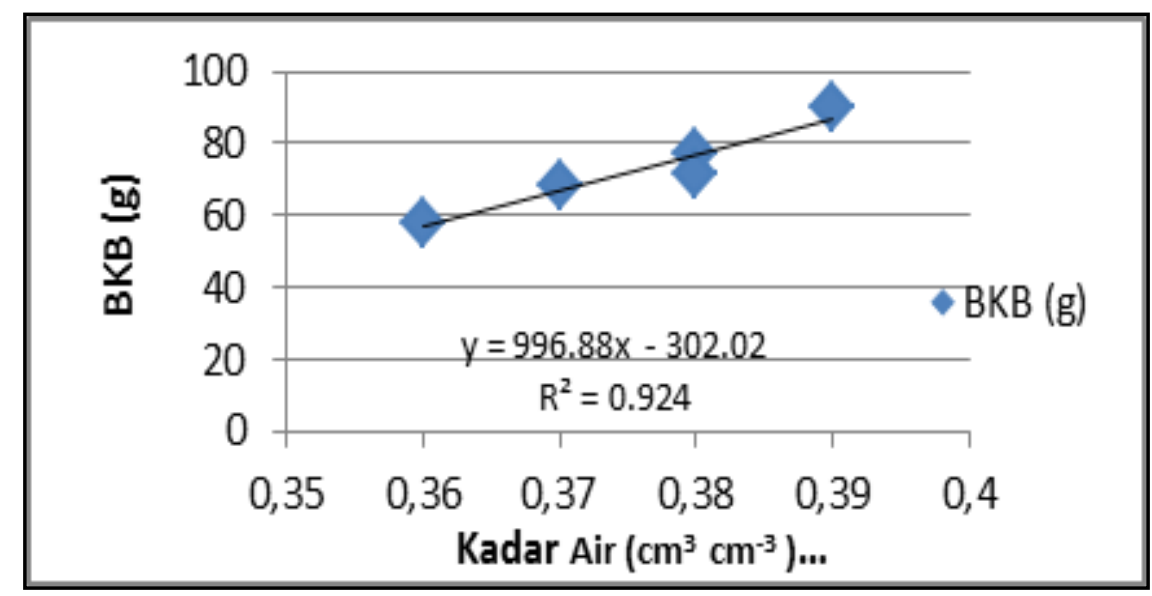

Figure 3: The relation between soil moisture content at field capacity ( $\mathrm{pF} 2.5)$ and shoot dry weight of maize $(\mathrm{BKB})$

Based on the result of correlation and regression test between field moisture capacity and dry weight of plant under manure treatments with different soil depth, the coefficient of determination on topsoil $\mathrm{R} 2=0.924$, and on subsoil $\mathrm{R} 2=0.042$. The linear regression equation shows that the dry weight of plant is strongly influenced by the field moisture capacity. Rahman et al. (2004) found that in conditions of drought (very low soil water available) can affect plant growth and leaf area. This can reduce dry weight of plant. Camacho and Caraba (1994) found that maize plants with drought stress during their vegetative growth stages produced the smaller leaf growth. While Boutra et al. (2010) found that maize crops experiencing soil moisture deficit produced the lower leaf area.

\section{Conclusion}

Applications of sheep manure 10 tons ha- ${ }^{1}$ into soil have the effects on:

1) Increased growth of maize: plant height $(\mathrm{cm})$, stem diameter $(\mathrm{mm})$, leaf area $(\mathrm{cm})$, fresh weight and dry weight of stover (shoot) $(\mathrm{g})$.

2) Improvement of topsoil characteristics $(0-20 \mathrm{~cm})$ : soil bulk density, soil particle density, soil porosity and field moisture capacity

3) Improvement of subsoil characteristics $(20-40 \mathrm{~cm})$ : soil bulk density and particle density 
4) Decrease in soil porosity and available moisture content at $20-40 \mathrm{~cm}$ of soil depth.

\section{References}

[1] Agbede,T.M., S.O.Ojeniyi and A.J. Adeyemo. 2008. Effect of Poultry Manure on Soil Physical and Chemical Properties, Growth and Grain Yield of Sorghum in Southwest, Nigeria. AmericanEurasian Journal of Sustainable Agriculture, 2(1): 72-77.

[2] Agbogidi,O.M, and C.U.Okonmah. 2012. Growth and Yield of Maize as Influenced by Organic Manure type in a Niger Delta Environment. International Journals of Agriculture and Rural Development (IJARD), 15 (1): 818-824.

[3] Basamba,T.A., E.Barrios, E.Ame'zquita, I.M. Rao and B.R. Singh. 2006. Tillage effects on maize yield in a Colombian savanna oxisol: Soil organic matter and $\mathrm{P}$ fractions. Soil \& Tillage Research, 91: 131-142.

[4] Baskoro, D. P. T. and S. D. Tarigan. 2017. Characteristics of soil moisture at several soil types (Karakteristik Kelembaban Tanah pada Beberapa Jenis Tanah). Journal of Soil and Environment, 9 (2): 77-81.

[5] Boateng,S.A., J.Zickermann and M. Kornahr. 2006. Poultry Manure Effect on Growth and Yield of Maize. West Africa Journal of Applied Ecology (WAJAE), 9: 1-11.

[6] Bodansari, S.B.S. 2012. Effects of zeolite and manure on several physical characteristics of Ultisol and Entisol under soybeans cropping system (Pengaruh Zeolit dan Pupuk Kandang Terhadap Beberapa Sifat Fisik Tanah Ultisol dan Entisol Pada Pertanaman Kedelai ( Glicine Max L. Merril). Journal of Rural Development, 12(2) : 113-122.

[7] Bouajila,K. and M. Sanaa. 2011. Effects of organic amendments on soil physico-chemical and biological properties. J.Mater. Environ. Sci., 2 (S1) 2011 485-490.

[8] Boutra, T., A. Akhkha, A.Abdulkhaliq, Al-Shoaibi and A.M.Alhejeli. 2010. Effect of water stress on growth and water use efficiency (WUE) of some wheat cultivars (Triticum durum) grown in Saudi Arabia. Journal for Science of Taibah University, 3: 39-48. Available online at www.taibahu.edu.sa ISSN: 1658-3655.

[9] Camacho, R.G. and D. F. Caraba. 1994. Evaluation of Morphological Characteristics in Venezuelan Maize (Zea Mays L.) Genotypes under Drought Stress. Sci. agric. (Piracicaba, Braz.), 51(3): 453-458.

[10] Da Costa, J.A., H.S.Bambang, G.Totok, and N.A.U.Sri. 2015. Land evaluation as a foundation of annual crop development (Case in the Raumoko Lutem Timor Leste) (Evaluasi Lahan Untuk Dasar Pengembangan Pertanian Tanaman Semusim (Kasus di Raumoko Lutem Timor Leste). Journal of Galung Tropics, 4(2): 121-130.

[11] Dao,T.H. 1993. Tillage and winter wheat residue management effects on water infiltration and storage. Soil Sci. Soc. Am. J., 57: 1586-1595.

[12] Dermiyati. 2015. Sustainable organic farming systems (Sistim Pertanian Organik Berkelanjutan). Yogyakarta. p.33.

[13] Esmaeilzadeh,J. and A.G.Ahangar. 2014. Influence of Soil Organic Matter Content on Soil Physical, Chemical and Biological Properties. International Journal of Plant, Animal and Environmental Sciences, 4(4): 244-252.

[14] Franzluebbers, A.J.2002. Water infiltration and soil structure related to organic matter and its stratification with depth. Soil \& Tillage Research, 66: 197-205.

[15] Hanafiah, K. A. 2014. Foundation of Soil Science (Dasar-Dasar Ilmu Tanah). Raja Grafindo Persada. Jakarta. P.79-81.

[16] Huang,R., C.J.Birch and D.L.George. 2006. Water Use Efficiency in Maize Production - The Challenge and Improvement Strategies. 6th Triennial Conference 2006. Shenyang Agricultural University, Liaoning Province, 110161, PR China rhuang_syau@ @otmail.com. 
[17] Hudson, B. 1994 .Soil organic matter and available water capacity. J. Soil Water Conserv., 49:189-193.

[18] Intara,Y.I., A.Sapei, E.N.Sembiring and M.H.B.Djoefrie, 2011. Effects of organic matter application into clay-soil and clayey-loam soils on soil-moisture retention (Pengaruh Pemberian Bahan Organik Pada Tanah Liat, Lempung Berliat Terhadap kemampuan Mengikat Air). Journal of Indonesian Agriculture Science, 16(2) : 130-135.

[19] Istiqomah,D.N., D.Gustomo and S. Prijono. 2015. Evaluation of combination of organic fertilizer and Biourine of rabbit on stability of soil aggregates and sugarcane growth (Uji Efektivitas Kombinasi Jenis Pupuk Organik Dan Biourin Kelinci Terhadap Kemantapan Agregat Dan Pertumbuhan Tebu Pada Fase Pertunasan). Journal of Soil and Land Resources, 2(1): 129137.

[20] Karami, A., M.Homaee, S.Afzalinia, H.Ruhipour and S.Basirat. 2012. Organic resource management: Impacts on soil aggregate stability and other soil physico-chemical properties. Agric Ecosyst. Environ 148: 22-28.

[21] Kihanda, F.M., G.P.Warren, and A.N.Micheni. 2006. Effect of manure application on crop yield and soil chemical properties in a long-term field trial of semi-arid Kenya. Nutr. Cycl. Agroecosys. 76: 341-354.

[22] Kresnatita, S., Koesriharti and M. Santoso. 2017. Effects of organic manure on growth and yield of sweetcorn (Pengaruh Rabuk Organik Terhadap Pertumbuhan dan Hasil Tanaman Jagung Manis). Indonesian Green Technology Journal, 2(1): 8-15.

[23] Kurnia,U., L.N.Nurida and H. Kusnadi. 2006. Field measurement of soil moisture retention (Penetapan Retensi Air Tanah di Lapangan). Indonesian Agency for Agricultural Research and Development, Indonesian Ministry of Agriculture. P.156.

[24] Mahmood,F., I.Khan, U.Ashraf, T.Shahzad, S. Hussain, M. Shahid, M. Abiddan and S.Ullah. 2017. Effects Of Organic and Inorganic Manures On Maize And Their Residual Impact On Soil Physico-Chemical Properties. Journal of Soil Science and Plant Nutrition, 17(1): 22-32.

[25] Mahmood,F., I.Khan, U.Ashraf, T.Shahzad, S.Hussain, M.Shahid, M.Abid and S.Ullah. 2017. Effects of organic and inorganic manures on maize and their residual impact on soil physicochemical properties. Journal of Soil Science and Plant Nutrition, 17(1): 22-32.

[26] Mikha,M.M. and C.W.Rice. 2004. Tillage and manure effects on soil and aggregate-associated carbon and nitrogen. Soil Sci.Soc.Am.J., 68: 809-816.

[27] Mosaddeghi,M.R., M.A.Hajabbasi, A.Hemat and M.Afyuni. 2000. Soil Compactibility by Soil Moisture Content and Farmyard Manure IN cental Iran. Soil \& Tillage Research, 55 : 87-97.

[28] Mucheru-Muna,M., D.Mugendi, J.Kung'u, J.Mugwe and A.Bationo. 2007. Effects of organic and mineral fertilizer inputs on maize yield and soil chemical properties in a maize cropping system in Meru South District, Kenya. Agroforest Syst., 69:189-197.

[29] Munir, H.M. 1096. The Major Soils in Indonesia (Tanah-Tanah Utama Indonesia). DiniaPustaka-Jaya Publ... Jakarta. p.311.

[30] Muyassir, Sufardi and I.Saputra. 2010. Changes of physical characteristics of Inceptisol-soil due to manure application (Perubahan Sifat Fisika Inceptisol Akibat Perbedaan Jenis dan Dosis Pupuk Organik). Lentera, 12(2): 37-48.

[31] Nariratih,I., M.M.B.Damanik and G.Sitanggang. 2013. Soil Nitrogen availability under manure application and N-uptake of maize (Ketersediaan Nitrogen Pada Tiga Jenis Tanah Akibat Pemberian Bahan Organik dan Serapannya Pada Tanaman Jagung). Online Journal of Agroecotechnology, 1 (3) : 2337-6597.

[32] Nasiu,F. 2012. Utilization of marginal drylands involving integration system of foodcrop, foragecrop and ruminant (Pemanfaatan Lahan Kering Marginal melalui Integrasi Tanaman Pangan, Tanaman Pakan, dan Ternak Ruminansia). PostGraduate Program, University of Gajahmada, Yogyakarta.

[33] Negassa,W., K.Negisho, D.K.Frison, J.Ransom and A.Yadessa. 2001. Determination of optimum FYM and NP fertilizers for maize on farmers' field. Soil. Sci. Soc. Am. J., 56: 476-484. 
[34] Nuro,F., D.Priadi and E.S. Mulyaningsih. 2016. Effects of organic fertilizer on soil properties and yield of vegetable (Efek Pupk Organik Terhadap Sifat Kimia Tanah dan Produksi Kangkung (Ipomoae reptans Poir). Proceedings National Seminar on Research Results of PPM IPB. ISBN : 978-602-8853-29-3 : 29-39. http://lppm.ipb.ac.id/wp-content/uploads/2014/10/Prosiding-LPPM2016.pdf

[35] Oades, J. M. 1984. Soil organic matter and water stable aggregates in soils. Plant and Soil, 76: 319-337.

[36] Okoroafor,I.B., E.O.Okelola, O.Edeh, V.C.Nemehute, C.N.Onu, T.C.Nwaneri and G.I.Chinaka. 2013. Effect of Organic Manure on the Growth and Yield Performance of Maize in Ishiagu, Ebonyi State, Nigeria. IOSR Journal of Agriculture and Veterinary Science (IOSR-JAVS), 5(4): 28-31.

[37] Putra,I., Soemarno and R.Suntari. 2016. Humification Degree and Its Relationship With Some Soil Physical Charactersticas on Rebusta Coffe (Coffea canephora) Plantation. Journal of Degraded and Mining Land Management, 3(4): 649-658.

[38] Rachman, S. 2002. Implementation of Organic Farming (Penerapan Pertanian Organik). Kanisius Publ. Yogyakarta. P.20-25

[39] Rachman,L.M., L.Nisa and L.N.Neneng. 2015. Effects of soil tillage systems on soil organic matter and maize yield at yellow-red Podzolic soil, district of East Lampung. (Efek Sistim Pengolahan Tanah Terhadap Bahan Organik Sifat-Sifat, dan Produksi Jagung Pada Tanah Podsolik Merah Kuning Dikabupaten Lampung Timur). Proceeding National Seminar on Suboptimal Land Resources. ISBN: 979-987-580-9. Latmara-59@yahoo.com.

[40] Rahman,M.U., S. Gul and I. Ahmad. 2004. Effects of Water Stress on Growth and Photosynthetic Pigments of Corn (Zea mays L.) Cultivars. International Journal of Agriculture \& Biology, 1560-8530/2004/06-4-652-655.

[41] Rahmi and Jumiati. 2007. Effects of concentration and time application of liquid organic fertilizer of Super-ACI on growth and yield of sweetcorn. (Pengaruh Konsentrasi dan Waktu Penyemprotan Pupuk Organik Cair Super ACI Terhadap Pertumbuhan dan Hasil Jagung Manis). Journal of Agritop, 26 (3): xx.

[42] Rizqullah,Helmi, Sitawati and B.Guritno. 2017. The Effect of Kinds And Application Organic Fertilizer on The Growth And Sweet Corn Production (Zea mays saccharata Sturt.) Jurnal Produksi Tanaman, 5(3): 383-389.

[43] Shalsabila, F., S. Prayono and Z. Kusuma. 2017. Application of cacao waste biochar in improving soil aggregates stability and maize yield. (Pengagruh Aplikasi Biochar Kulit Kakao Terhadap Kemantapan Agregat Tanah dan Produksi Tanaman Jagung). Journal of Soil and Land Resources, 4(2): 473-480.

[44] Shortall,J.G. and W.C.Liebhardt. 1975. Field and growth of corn as affected by poultry manure. J. Environ. Qual., 4(2): 186-191.

[45] Simarmata,T. and R.Hindersah. 1999. Optimal application of Biofertilizer in improving land productivity and sustainable agriculture (Optimalisasi Aplikasi Pupuk Biologis untuk Meningkatkan Produktivitas Lahan Menuju Pertanian Berkelanjutan). Proceeding National VII Indonesian Society of Soil Science, Bandung. P.729-736.

[46] Singh,J., A.Salaria and A.Kaul. 2014. Impact Of Soil Compaction On Soil Physical Properties And Root Growth: A Review. International Journal of Food, Agriculture and Veterinary Sciences ISSN: 2277-209X (Online) An Open Access, Online International Journal , 5 (1) : 2232.

[47] Subaedah,S., A.Aladin and Nirwana, 2016. Fertilization of Nitrogen, Phosphor and Application of Green Manure of Crotalaria juncea In Increasing Yield of Maize in Marginal Dry Land. Agriculture and Agricultural Science Procedia, 9: 20-25.

[48] Sukmawati. 2015. Availability of soil organic carbon in drylands under alley cropping systems (Analisis Ketersediaan C-Organik Di Lahan Kering Setelah Di Terapkan Berbagai Model Sistim Pertanian Hedgerow). Journal of Galung Tropics, 4 (2) : 115-120. 
[49] Sumarni, N., R. Rosliani and A.S.Duriat. 2010. Management of soil physico-chemistry and soilbiology in improving soil fertility and yield of red-pepper. (Pengolahan Fisik Kimia dan Biologi Tanah Untuk Meningkatkan Kesuburan Lahan dan Hasil Cabe Merah). Journal of Resources and Environment. 20 (2):xx.

[50] Surya,A.S., Y.Nuraini, and Widianto. 2017. Study of soil porosity under organic matter application in the Robusta coffea plantation. (Kajian Porositas Tanah Pada Pemberian Beberapa Jenis bahan Organik Di Perkebunan Kopi Robusta). Journal of Soil and Land Resources, 4(1): 463-471.

[51] Tangkoonboribun, R., S. Ruaysoongnern, P. Vityakon, B. Toomsan and M.S.Rao. 2007. Effect of organic ameliorants to improve soils using sugarcane as a model. The XXVI Congress, International Society of Sugar Cane Technologists, ICC, Durban, South Africa.

[52] Tisdall,J.M. and J.M.Oades. 1982. Organic matter and water stable aggregates in soils. Journal of Soil Science, 33: 141-163.

[53] Wahyunie,E.D., D.P.T.Baskoro and M. Safyan. 2012. Soil moisture retention and penetration resistance of soil under intensive soil tillage and conservation tillage (Kemampuan Retensi Air Dan Ketahanan Penetrasi Tanah Pada Sistim Olah Tanah Intensif dan olah Tanah Konsevasi). Journal of Soil and Environment, 14(2): 73-78.

[54] Wang,X., Yuanyuan, S.Zhan, Y.Chen and N.Wang. 2017. Apication of Organic Manure Increased Maize (Zea mays L.) Yiaid and Water Productivity in a Semi-arid Region. Agricultural Water Management, 187: 88-98.

[55] Wigena, P. G., L. Angaria and J. Purnomo. 2015. Technology of nutrients and organic matter in the sustainable drylands farming at the arid region (Teknologi Pengelolaan Hara Dan Bahan Organik Sebagai Model Pertanian Ramah Lingkugan Lahan Kering Beriklim Kering). Soil Research Institute, Indonesian Ministry of Agriculture. file://C:/Users/ ADMIN/Downloadsb teknologi _wigena.pdf.

[56] Zhang,P., T.Wei, Z.Jia, Q.Han, X.Ren, and Y. Li. 2014. Effects of Straw Incorporation on Soil Organic Matter and Soil Water-Stable Aggregates Content in Semiarid Regions of Northwest China. PLoS One, 9(3): e92839.

[57] Zulkarnain, M., B. Prasetya and Soemarno. 2012. Effects of compost, manure, and Cuntom-Bio on soil characteristics, growth and yield of sugarcane at Entisol soil, Kediri (Pengaruh Kompos, Pupuk Kandang, dan Custom-Bio terhadap Sifat Tanah, Pertumbuhan dan Hasil Tebu (Saccharum officinarum L.) pada Entisol di Kebun Ngrangkah-Pawon, Kediri). Indonesian Green Technology Journal, 2(1): 45-52.

*Corresponding author.

E-mail address: saidfernandes31@gmail.com 